\title{
Glimpses of \\ Unsurveyable Maps
}

\author{
David Wagner, Vienna
}

That Ludwig Wittgenstein was interested in maps and map-making comes as no surprise. After all, he compares the form of a philosophical question to our common experience of disorientation-'I don't know my way about.' (PI § 123) ${ }^{1}$ — and likens his Philosophical Investigations (PI) to an album containing sketches of a landscape which has been explored in a criss-cross manner. In this paper I present metaphors of perfect maps provided by Jorge Luis Borges, Lewis Carroll and Josiah Royce, and set these against remarks by Wittgenstein and Charles Sanders Peirce.

Even this - slightly expanded-version of the talk I gave at the 33rd International Wittgenstein Symposium is, however, far from a survey of literary maps and their inspirational potential for philosophy. I would simply like to offer a series of glimpses at literary maps that might enrich a larger picture.

The larger picture consists in the view that the young Wittgenstein subscribed to a picture-theory of truth, a correspondence theory that understands correspondence between the structure of truth-bearers and states of affairs as congruence. While this is uncontroversial, I would here like to add illustrations that make it plausible that Wittgenstein had no reason to abandon his picture-theory, rather, that his thinking about maps - if understood as an expression of this theoretical position-, particularly in the writings from 1930 to the gestation of the Brown and Blue Books, may have evolved from this early Tractarian notion.

If one looks at the most pertinent metaphor for the picture-theory, the mirroring or picturing of formal relations in the way markings on a map mirror the structure of that portion of the world of which it is a map, it is helpful to consider extreme examples of maps. Unsurveyable maps as thought 
experiments by writers and philosophers show us why surveyability is such a key quality of a map.

While part one of this paper revolves around an essentialistic picture theory that supposes that there is but one ideal language mapping the sayable, and one ideal of exactness, part two of the paper explores the idea that various maps with various practical purposes make the existence of the one all-encompassing language obsolete.

\section{Seeing connections}

In his collection of fake historical fragments entitled Museum [1946] the Argentinean writer Jorge Luis Borges provides us with a description of 'perfect' map-making. His short text, titled 'On Scientific Rigor (Del rigor en la ciencia)' is an imaginary example of scientific self-destruction. Apparently taken from a 17th century history book, the story tells of a nameless Empire in which Schools of Cartography are held captive by their picture of exactitude:

... In the Empire in question, the Cartographer's Art reached such a degree of Perfection that the map of a single Province took up an entire City, and the map of the Empire covered an entire Province. After a while these Outsized Maps were no longer sufficient, and the Schools of Cartography created a Map of the Empire that was the size of the Empire, matching it point by point. Later Generations, which were less Devoted to the Study of Cartography, found this Map Irrelevant, and with it more than a little Irreverence left it exposed to the Inclemencies of the Sun and Winter. In the Western desert there are still Ruins of the Map, inhabited by Animals and Beggars. No other relics of the Geographic Discipline can be found anywhere else in the Land. ${ }^{2}$

The core idea of this story may have sprung from an earlier work, one by Lewis Carroll. The novel in which we find it, Lewis Carroll's Sylvie and Bruno Concluded [1893], was well-known to Borges ${ }^{3}$ and admired by such diverse writers as James Joyce and Ludwig Wittgenstein ${ }^{4}$. As in the version of Borges, we are presented with a map too big for its own good:

"What a useful thing a pocket-map is!" I remarked.

"That's another thing we've learned from your Nation," said Mein Herr, 
"map-making. But we've carried it much further than you. What do you consider the largest map that would be really useful?"

"About six inches to the mile."

"Only six inches!" exclaimed Mein Herr. "We very soon got to six yards to the mile. Then we tried a hundred yards to the mile. And then came the grandest idea of all! We actually made a map of the country, on the scale of a mile to the mile!"

"Have you used it much?" I enquired.

"It has never been spread out, yet," said Mein Herr: "the farmers objected: they said it would cover the whole country, and shut out the sunlight! So we now use the country itself, as its own map, and I assure you it does nearly as well. [...]"5

Using a country as its own map is comparable to Jonathan Swift's Lagadonian language. Wittgenstein knew Gulliver's Travels [1726] well, in fact, he even read an abridged version of it with his pupils at the primary school in Trattenbach. ${ }^{6}$ In chapter five Samuel Gulliver visits the Grand Academy of Lagado on the island of Balnibarbi, where he learns about the scientific endeavours to create a perfect language:

We next went to the school of languages, where three professors sat in consultation upon improving that of their own country.

The first project was to shorten discourse, by cutting polysyllables into one, and leaving out verbs and participles; because in reality all things imaginable are but nouns.

The other project was a scheme for entirely abolishing all words whatsoever; and this was urged as a great advantage in point of health as well as brevity. For it is plain that every word we speak is, in some degree, a diminution of our lungs by corrosion, and consequently contributes to the shortening of our lives. An expedient was therefore offered, and since words are only names for things, it would be more convenient for all men to carry about them such things as were necessary to express a particular business they are to discourse on. $[\ldots]$ $[\mathrm{M}]$ any of the most learned and wise adhere to the new scheme of expressing themselves by things; which has only this inconvenience attending it, that if a man's business be very great, and of various kinds, he must be obliged, in proportion, to carry a greater bundle of things upon his back, unless he can afford one or two strong servants to attend him. I have often beheld two of these sages almost sinking under the weight of their packs, like peddlers among us; 
who, when they met in the street, would lay down their loads, open their sacks, and hold conversation for an hour together; then put up their implements, help each other to resume their burdens, and take their leave. ${ }^{7}$

In PI $\S 6$ Wittgenstein reminds us that ostensive teaching of words may establish 'an associative connection between word and thing', which means, amongst other things, that 'a picture of the object comes before the child's mind when it hears the word' (PI §6). This is quite desirable, for example when we read poetry or novels, but it also has its disadvantages: We tend to take our pictorial associations for granted and forget that what words mean is not simply given. Using words across a variety of contexts, we tend to forget the language-game which caused us to associate a certain picture in the first place, 'the language in which it is at home' (PI § 116).

The more obvious problem illustrated by the Lagadonian language, however, is the fact that Lagadonian does not offer a solution to misunderstandings, to erroneous interpretations. While we can speak in English about an English sentence, Lagadonians only have rebus puzzles. For how would a Lagadonian in his 'perfect' language communicate that the red square he is showing to someone is only meant to convey the colour red, but not its rectangular shape? By pointing to it?

Just as maps do not simply show us isolated markings but provide markings in relation to each other, the picture-theory is not so much concerned with singular words and the objects they pick out, but with structural complexes: sentences. To see structures means that one has selected certain relations above others. And this is why unsurveyable maps like the ones by Borges and Carroll fail: They show too much. They are the endpoints of cartography, where abundance of detail has won over clarity of communication.

Before I move on, let me summarise. Swift's Lagadonian language shares one important feature with Borges' and Carroll's maps: it is highly impractical. While the giant maps block out the sun and at best serve as shelter for the poor, they have stopped being maps, since the purpose of a map is to give instructions we can follow, that we may transfer its picture into our actions:

Die Verwendung einer Landkarte besteht darin, daß wir uns in irgendeiner Weise nach ihr richten; daß wir ihr Bild in unsere Handlungen übertragen. (Wittgenstein, MS 114, p. 51) 
Faced with these gigantic maps, the problem one encounters is the very reason maps were invented in the first place. For maps are drawn to provide us with orientation in a country 'deficient in surveyability. A surveyable representation produces precisely that understanding which consists in "seeing connections", (PI § 122) and dissolves the feeling of not knowing one's way about:

Es ist, wie wenn ich ein winziges Gesichtsfeld und ein schlechtes Gedächtnis hätte, und nun, durch hin und her blicken, mich auf einer großen Landkarte auszukennen lernen sollte. Man würde in so einem Falle fortwährend Zusammenhänge vergessen, verkennen, sie langwierig suchen, wo sie nicht sind. (Wittgenstein, MS 117, p. 220)

\section{Seeing differences}

Our third map is by Josiah Royce, who invented it for a supplementary essay of his opus magnum The World and the Individual $[1899]^{8}$. To Borges this 'philosophical' map is clearly on a par with the best of literary inventions. ${ }^{9}$

Bertrand Russell discusses it in chapter 8 ('Infinite Cardinal Numbers') of his Introduction to Mathematical Philosophy [1919].-I quote Russell:

A "reflexive" class is one which is similar to a proper part of itself. (A "proper part" is a part short of the whole.)

A "reflexive" cardinal number is the cardinal number of a reflexive class.

We have now to consider this property of reflexiveness.

One of the most striking instances of a "reflexion" is Royce's illustration of the map: he imagines it decided to make a map of England upon a part of the surface of England. A map, if it is accurate, has a perfect one-one correspondence with its original; thus our map, which is part, is in one-one relation with the whole, and must contain the same number of points as the whole, which must therefore be a reflexive number. Royce is interested in the fact that the map, if it is correct, must contain a map of the map, which must in turn contain a map of the map of the map, and so on ad infinitum. ${ }^{10}$

One interesting aspect of Royce's map is the feeling of dizziness that grabs hold of the reader, as he tries to reconstruct the map-within-the-map in his mind. A disorientation of another kind. 
Ever since Carl Friedrich Gauss wrote his treatise 'Allgemeine Auflösung der Aufgabe: Die Theile einer gegebnen Fläche auf einer andern gegebnen Fläche so abzubilden, dass die Abbildung dem Abgebildeten in den kleinsten Theilen ähnlich wird' [1825], the terms prototype (Urbild) and projected pictorial form (Abbild) have been at home in the world of map-making. One important aspect of geodesic projection is the fact that prototype and depiction are never identical, they only come to be very much alike. In the case of a strong likeness - preserving both angles and shapes of infinitesimally small figures - one speaks of a conformal projection. A 'conformal' map simply conforms to the principle of angle-preservation. ${ }^{11}$

Few, if any, philosophers know more about maps than the geodesist and mathematician Charles Sanders Peirce. It is in his review of The World and the Individual that Peirce writes about Royce's perfect map and finds in it a confirmation of his own ideas concerning the self. Even though Royce states Georg Cantor's serial one-to-one mapping of odd-numbers onto integers as his source of inspiration, Peirce immediately thinks of Gaussian conformal projection:

[Royce] resorts to Gauss's conception of Abbild, which has played a great role in mathematics. That is to say, he likens the idea representing the entire life to a map of a country lying upon the territory of that country. Imagine a map of England, absolutely perfect in its minutest details, to lie upon the soil of England, without covering the entire country it maps. Upon this map would be shown the very ground where the map lies, and the map itself, in all its minutest details. In this map of the map, the map will be shown again; and so on endlessly. [...] It is to be noticed that, each successive map lying well inside the one which it immediately represents $[\ldots]$ the endless series of maps will converge to a single point, which represents itself throughout each and every map of the series. In the case of the idea, that point would be the self-consciousness of the idea. An idea, being a state of mind with a conscious purpose, must evidently be self-conscious. ${ }^{12}$

Peirce considers the map-within-the-map an apt metaphor for a self-representative system. He even goes one step further than Royce: Peirce insists that self-reference - in the map-metaphor that single point, where all maps of differing sizes converge - is essential to the continuum that gives us the feeling of remaining the same person over time: 
the man's Self encloses intermediate selves - the domestic Self, the business Self, the better Self, the evil spirit that sometimes usurps his sovereignty. [...] Every reality, then, is a Self, and the selves are intimately connected, as if they formed a continuum. Each one is, so to say, a delineation; with mathematical truth we may say, incongruous though the metaphor is, that each is a quasi-map of the entire field of all the selves $[\ldots]^{13}$

Speculations like these are not Russell's cup of tea. Regarding Royce's infinite maps-within-maps he simply says: 'This point is interesting, but need not occupy us at this moment. In fact, we shall do well to pass from picturesque illustrations to such as are more completely definite, and for this purpose cannot do better than consider the number-series itself.' ${ }^{14}$

Wittgenstein, who loved to dwell on picturesque illustrations, may have thought otherwise. He was well aware of the fact that in a contextual sense every useful map is a map-within-a-map. For what use would a map of Oxfordshire be to someone lost in Lower Austria? Just as the meaning of words relies on their context, a map only makes sense where (and for what purpose) we need it.

Even though the series of maps in Royce's thought experiment converge to a single point, each successive map depicts one specific aspect of the country, has its particular use. The information given on political maps, climate maps, road maps, underground maps, topographic maps and so on may converge at particular points, but as each map tells a different story, none of the maps will give all the information. The specific requirements for these maps inform the picture language (Bildsprache) the map-maker chooses. From the perspective of its user one could say that the one single perfect map does not exist, because each map is judged according to the requirements it meets. ${ }^{15}$

Using a map means following its rules, thus we may copy a map of trails by walking according to the information it gives (cf. MS 153b, 8v). This has important implications if one contemplates how a model of language may resemble a map. Language as a projection of reality, mirroring how the map shows relations of the landscape it depicts (cf. WA2: 184 1). But instead of solving linguistic problems of meaning, this metaphor only makes them more apparent. To really understand the map, to be able to read it and connect it to the landscape, requires that one does not overlook the differences amongst its markings: 
Vergleich der verschiedenen Arten von Linien auf der Landkarte, mit den Wortarten in den Sätzen. Der nichts davon versteht, sieht eine Menge von Linien und weiß nicht, daß sie sehr verschiedene Bedeutungen haben; es sind Straßen, Grenzen, Schichtenlinien, Meridiane, Schraffen, u. a.. Denke dir auf dem Plan wäre ein Weg eingezeichnet und (mit einigen Linien) durchstrichen - um anzudeuten, daß es diesen Weg gegeben habe, aber nicht mehr gebe. (Wittgenstein, MS 116, p. 28)

Seeing various lines on a map, without knowing what they stand for, may result in taking their linearity as the most important feature certainly one way of being held captive by a picture.

In 1930 Wittgenstein points out that certain features of commands and expectations can be made clear by reference to maps. Following an order (Befehl), we follow certain rules and the map becomes the picture we interpret: 'Die Landkarte ist das Bild[,] das interpretiert wird.' (WA2: 295 3) Here the map may still be a metaphor for language - but it does not simply show its relation, it requires an active interpretation. To understand the map is not the same as looking at it like an uninvolved spectator. We have to put ourselvessee our position - in relation to the markings on the map. ${ }^{16}$

But then, in close vicinity, Wittgenstein gives another example: Distances depicted on a map tend to ground the expectation for our arrival at a certain point in time: '[...] die Landkarte ist das Bild unserer Erwartung[,] indem sie zeigt[,] daß wir in einer Stunde dort und dort hin kommen.' (23. 7. 1930, WA2: 295 3) Here the map is the cause of our expectations, its relations make us expect something - like a command may make us act in a certain way. One fact remains the same, however: In order to serve as an image of our expectations, we must be in a position to read the markings on the map, to interpret the distances and make sense of it all.

In the lecture notes taken in 1933 by his students Alice Ambrose and Margaret Macdonald known as The Yellow Book, Ludwig Wittgenstein compares language to a country and map-making becomes the task of the philosopher. The method he suggests is akin to getting to know a country by repeated walks. The work of the philosopher of language is a survey culminating in a synoptic view:

One difficulty with philosophy is that we lack a synoptic view. We encounter the kind of difficulty we should have with the geography of a country for which we 
had no map, or else a map of isolated bits. The country we are talking about is language, and the geography its grammar. We can walk about the country quite well, but when forced to make a map, we go wrong. A map will show different roads through the same country, any one of which we can take, though not two, just as in philosophy we must take up problems one by one though in fact each problem leads to a multitude of others. We must wait until we come round to the starting point before we can proceed to another section, that is, before we can either treat of the problem we first attacked or proceed to another. In philosophy matters are not simple enough for us to say "Let's get a rough idea", for we do not know the country except by knowing the connections between the roads. So I suggest repetition as a means of surveying the connections. (YB 2001, 43)

While Wittgenstein is at that time still unhappy about knowing only 'isolated bits' and a synoptic view figures as the ideal he strives for, it seems that providing sketches of a landscape is what he resigned himself to in the end. ${ }^{17}$

\section{Conclusion}

The above was meant to show that apparently useless maps may be useful after all. If only as inspirational material for philosophers. For Wittgenstein might just as well have heeded Descartes' advice that the best way out of a thicket is to continue in the direction once chosen. ${ }^{18} \mathrm{Had}$ Wittgenstein walked in a straight line rather than repeatedly taking detours, we would be one work of philosophy poorer, for it is his criss-cross manner of mapping thought that makes the landscape of his Philosophical Investigations so intriguing. 


\section{Notes}

1 Ludwig Wittgenstein, Philosophical Investigations, the German text, with an English translation by G. E. M. Anscombe, P. M. S. Hacker and Joachim Schulte, revised fourth edition by P. M. S. Hacker and Joachim Schulte (New York: Wiley, 2009).All references are made to the respective paragraphs using the siglum IP. Other reference keys to Wittgensteins writings are indicated in the bibliography.

2 Borges, Jorge Luis. 'On Scientific Rigor', in: Selected Poems, edited by Alexander Coleman (New York: Viking), 139.

3 E. g. Borges, Jorge Luis. 1999b. Selected Non-Fictions, edited by Eliot Weinberger, (New York: Viking), 215.

4 Cf. Pitcher George. 1967. 'Wittgenstein, Nonsense and Lewis Carroll', in: Ludwig Wittgenstein: The Man and His Philosophy, edited by K. T. Fann (New York: Dell), Fn5.-More information on occurrences of Carroll's writings in Ludwig Wittgenstein's Nachlass may be found in my paper 'The Uses of Nonsense: Ludwig Wittgenstein reads Lewis Carroll' in: Wittgenstein-Studien 3/2012, edited by Wilhelm Lütterfelds, Stefan Majetschak, Richard Raatzsch and Wilhelm Vossenkuhl (DeGruyter, 2012) (in preparation).

5 Carroll, Lewis. 1991. The Complete Sylvie and Bruno, (San Francisco: Mercury House), 265.

6 Cf. Letter to Ludwig Hänsel (30. 11. 1920) in: Wittgenstein, Ludwig. 2004. Complete Correspondence. The Innsbruck Electronic Edition. Edited by Monika Seekirchner, Anton Unterkirchner and Brian McGuinness. Charlottesville, Virginia: Intelex (Web-Edition).

7 Swift, Jonathan. 1892. Gulliver's Travels, (London: T. Nelson and Sons) $193 \mathrm{f}$.

8 Cf. Royce, Josiah. 1923. The World and the Individual, First Series (New York: Macmillan), $502 \mathrm{ff}$.

9 Cf. Borges, Jorge Luis. 1966. Das Eine und die Vielen. Essays zur Literatur (München: Hanser), 152.

10 Russell, Bertrand. 1920. Introduction to Mathematical Philosophy, second edition (London: George Allen \& Unwin) 80.

11 Cf. Gauss, Carl Friedrich. 1873. Werke, Band IV, (Göttingen: Königl. Ges. der Wissenschaften), $189 \mathrm{ff}$.

12 Peirce, Charles Sanders. 1979. Contributions to THE NATION, pt. 3 (Lubbock: Texas Tech Univ. Press) 83.

13 Peirce, Charles Sanders. 1979. Contributions to THE NATION, pt. 3 (Lubbock: Texas Tech Univ. Press.) 84. 
14 Russell, Bertrand. 1920. Introduction to Mathematical Philosophy, second edition. (London: George Allen \& Unwin), 80.

15 A related point is made by Hana Gründler in her perceptive paper "Eine Menge von Landschaftsskizzen." Zur Bedeutung des Zeichnerischen in Ludwig Wittgensteins Spätphilosophie' in volume one of Image and Imaging in Philosophy, Science and the Arts, Proceedings of the 33rd International Ludwig Wittgenstein Symposium, edited by Richard Heinrich, Elisabeth Nemeth, Wolfram Pichler and David Wagner (Heusenstamm bei Frankfurt: ontos Verlag, 2011), 1-22.Gründler points out that it is less easy to discern the borders of an object in line drawing, once singular clear contours have been replaced by the multiplicity of lines that constitute a sketch. The apparent loss of clarity comes, however, hand in hand with a more natural depiction of the object - one gains the impression of volume. Artists and philosophers both generate perspectives on their object of interest without claiming that any of their respective views is the only viable one.

16 Cf. this example from February 1931 (MS 110): 'Ich erkläre jemanden einen Plan und wie er zu gehen hat und sage, auf eine Stelle des Planes zeigend: "Hier stehen wir; du gehst .... ." Nun sieht er die Karte anders. Verstehen ist nicht: ein Bild sehen, sondern, ein Bild in einer bestimmten Position.' (WA3: $19710 \mathrm{f}$.)

17 Hana Gründler suggests that Wittgenstein intentionally chose the form of sketching his thoughts rather than presenting them in a more worked-out and orderly fashion, because he imagined his ideal reader to be someone who prefers thoughtprovoking impulses to philosophical treatises. Cf. Gründler 'Landschaftsskizzen' (as in note 15), 11.

18 Gf. Descartes, René. 1953. 'Discours de la méthode pour bien conduire sa raison' in: Evres et Lettres, (Paris: Gallimard), 142.

\section{Literature}

Borges, Jorge Luis. 1966. Das Eine und die Vielen. Essays zur Literatur. München: Hanser. —. 1999a. 'On Scientific Rigor', in: Coleman, Alexander (ed.), Selected Poems, New York [et al.]: Viking, 139.

—. 1999b. Selected Non-Fictions, edited by Eliot Weinberger, New York [et al.]: Viking. Carroll, Lewis. 1991. The Complete Sylvie and Bruno, San Francisco: Mercury House.

Descartes, René. 1953. 'Discours de la méthode pour bien conduire sa raison' in: Evres et Lettres, Bibliothèque de la Pléiade, Paris: Gallimard, 125-179.

Gauss, Carl Friedrich. 1873. Werke, Band IV, Göttingen: Königl. Ges. der Wissenschaften. 
Peirce, Charles Sanders. 1979. Contributions to THE NATION, pt. 3, Lubbock: Texas Tech Univ. Press.

Pitcher, George. 1967. 'Wittgenstein, Nonsense and Lewis Carroll', in: Fann, K. T. (ed.), Ludwig Wittgenstein: The Man and His Philosophy, N. Y.: Dell.

Royce, Josiah. 1923. The World and the Individual, First Series, New York: Macmillan. Russell, Bertrand. 1920. Introduction to Mathematical Philosophy, second edition. London: George Allen \& Unwin.

Swift, Jonathan. 1892. Gulliver's Travels, London: T. Nelson and Sons.

Wittgenstein, Ludwig. 1999a. Wiener Ausgabe, Studien Ausgabe, volume two [= MS 107 and MS 108]. Vienna / New York: Springer. (WA2)

—.1999b. Wiener Ausgabe, Studien Ausgabe, volume three [= MS 109 and MS 110]. Vienna / New York: Springer. (WA3)

- 2000. Wittgenstein's Nachlass, The Bergen Electronic Edition, Oxford University Press, University of Bergen, The Wittgenstein Trustees. (MS)

—. 2001. 'The Yellow Book (Selected Parts)'. In: Wittgenstein's Lectures, Cambridge, 1932-1935, from the notes of Alice Ambrose and Margaret Macdonald, edited by Alice Ambrose. New York: Prometheus, 41-73. (YB)

—. 2009. Philosophical Investigations, revised fourth edition by P. M. S. Hacker and Joachim Schulte. New York: Wiley. (PI)

- Complete Correspondence. The Innsbruck Electronic Edition. Edited by Monika Seekirchner, Anton Unterkirchner and Brian McGuinness. Charlottesville, Virginia: Intelex (Web-Edition). (ICE) 